163.

$$
\text { ホールドオーバーサブレッションの臨床経験について }
$$

Clinical Experience of Hold Over Suppression

放医研病院部 ○千尾武彦 フィリッブス・メディカル・システムス 田中良一

【目的】MR検查に於ける分解能の向上で最も简単な方法はFOVを小さくすることであるが，それと比例して F O Vより被写体が大きくなった場合には折り返しによるアーチファクトの問題が生じる.

今回新しいソフトウェアが進入されたことによりこの問題が解決されたのでその使用経娩を報告する.

【方法】頭部用コイルを用いて人の頭部とファントムを，またボティーコイルを用いて人の骨盤坥をホールドオーハ

ーサブレッション機能を使ったものと使わなかったもので振像し $\mathrm{S} / \mathrm{N}$, 分解能を比校し検討を加えた。

また，骨盤部の撮像時にアルミホイルを巻いて行うものを追加し，同樣の検討を行った.

【結果】ホールドオーバーサブレッション機能を用いて撮像を行った場合，アルミホイルを巻いた場合よりも $\mathrm{S} / \mathrm{N}$ の者化無しに良好な画像が得られた。特に小さな領域ではこれまで位相エンコードの折り返しによるアーチフ

アクトを気にする必要がなく臨床上有用であった。

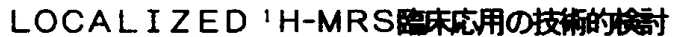

164. Technical Study For Clinical Use Of Localized 'H-MRS

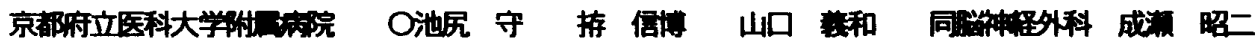

局在 ${ }^{1}$ H-MRSには多くの方法があるが、我々はStimulated echo(STEAM)法を用いている。STEN法てはエコ一时间(TE),STEAM

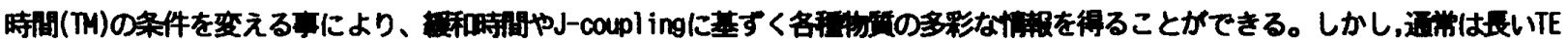

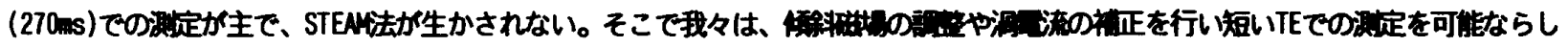

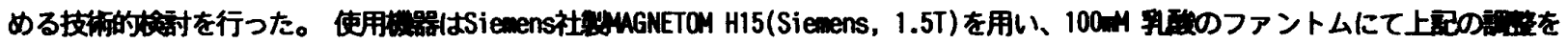

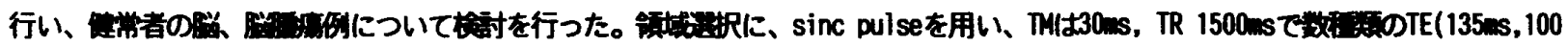

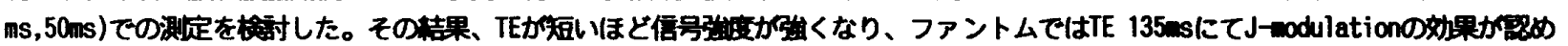

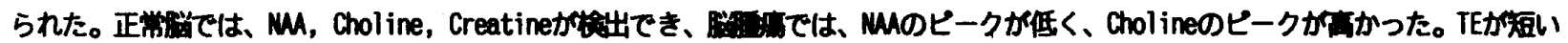

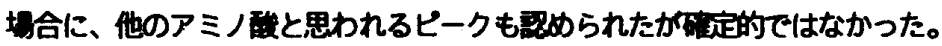

\section{Characterstic feature of volume selection and exitation width of 1H-MRS}

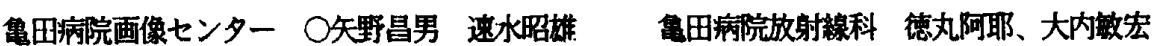

$1 \mathrm{H}$ は出現する信号が狭い周波数帯域に存在し、感度も優れていると言う点で他の核に比へて領城選択MR Sに道していると考え られる。我々はSTE AM法を用いて人体頭部の1 H-MRSを睍定しているが、このパルスシーケンスで得られる信号がどの栐なス ライス断面を持つかその特性と、領城题択の大きさを変化させた場合の领起周波数特性を調べたのでこれを報告する。

装望はMAGNETOM 1.5Tで、コイルは直径 $65 \mathrm{~mm}$ \% $1 \mathrm{H}$ 用サーフェイスコイルを用いた。スライス選択の特性を調べ るため直径 $5 \mathrm{~mm}$ m球形のガラス管に入ったファントムを用いて选択領城をシフトさせて信号強度を睻定し、スライス断面の特性を求 めた。

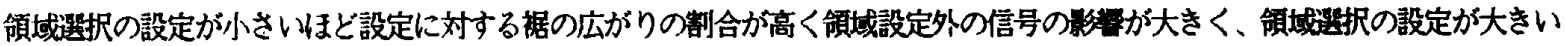
ほどその影数が少ない。

166.

$$
\text { F - } 19 \text { M R S による抗生剂の生体内挙動の測定 }
$$

-ーファントームによる基礎的検討 - -

$$
\text { 名古屋大学医学部附属病院放射線部 ○成田廣幸阿知波正用本間光彦山口宏 }
$$

【目的】オキサセフェム系抗生剤であるフロモキセフナトリウム(フルマリン)は、1 分子あたり 2 個のF原子を 含む。従って、フロモキセフナトリウムを静注した際に、生体内挙動の測定を、非钼血的に行なう手法として、F一 19 の M S 利用が考えられる。そこで、フロモキセフナトリウム箵度と、F 19 用サーフェイスコイルの感度との 関係について、基礎データーを得ることを目的とする。

【方法】フロモキセフナトリウムの正常成人での血中渻度を参考にして、ファントーム内のフロモキセフナトリウ ム濃度を $4 \mathrm{mg} / \mathrm{cc}$ から渐減し、5インチのF-19用サーフェイスコイルの感度特性を矵定する。

【結果】フロモキセフナトリウムを静注した際の、生体内挙動の测定を、F-199MRSにより行なうために必 要な基整データーを得ることができた。 